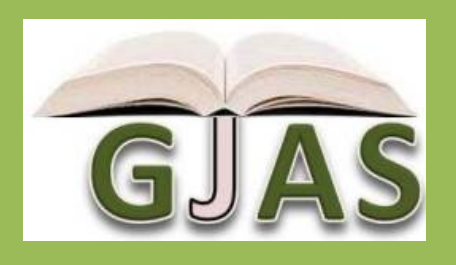

\title{
Estimation of the Effect of Water Temperature on the Growth of the Rainbow Trout (Oncorhynchus mykiss) with Poisson Regression Analysis
}

\author{
Atilla Taskin ${ }^{\star 1}$, Ufuk Karadavut ${ }^{1}$, Serkan Bektas ${ }^{2}$ \\ ${ }^{1}$ University of Ahi Evran, Agricultural Faculty, Depermant of Animal Science, Campus of \\ Aşıkpaşa-Kırşehir/Turkey. \\ ${ }^{2}$ Karaova Dam Fishery Products, Celebiusagi Village, Akpinar, Kırşehir/Turkey.
}

\section{ARTICLE INFO}

Article No.: 072313745

DOI: 10.15580/GJAS.2013.8.072313745

Submitted: $23 / 07 / 2013$

Accepted: 22/08/2013

Published: 29/08/2013

${ }^{\star}$ Corresponding Author

Atilla Taskin

E-mail: ataskin@ahievran.edu.tr

\section{Keywords:}

Rainbow trout, water temperature, growth, poisson regression
The aim of this study was to identify and assessthe growth retardation observed with increasing temperatures and led to economic losses at a rainbow trout (Oncorhynchus mykiss)farm at the Karaova Dam Lake within the province of Kirsehir, and to perform a poissonregression analysis and estimation on the effect of temperature. During the study, fish demonstrating signs of growth retardation were identified. For the studied rainbow trout, the value of the Pearson statistic was determined as 9.14, the deviation statistic as 7.53, and the artificial $R^{2}$ as 78.15 , and the Chisquared goodness of fit as 21.11.Based on the poissonregression analysis, it was determined that temperature levels had an adverse effect on fish growth. 


\section{INTRODUCTION}

Having considerable importance, trout is highly consumed by the local people of the region and all the world. However, numerous factors can adversely affect fish cultivation and productivity. One of the most significant factors that interferes with fish growth and leads to low productivity is water temperature (Dikel, 2009). This is because temperature has a key role on the physiological processes of fish (Brett ve Groves 1979). One of the most important aspects of fish physiology is arguably the effect of temperature on food intake.

Grans at al. (2013) explained that temperature affects on blood flow, gut motility, cardiac output, heart rate and cardiac stroke volume in different temperature (in vivo at 4,9 and $14{ }^{\circ} \mathrm{C}$.) Larsen at all (2012) determined that grown in rainbow trout 19 degrees $C$ routine metabolic rate (RMR), specific growth rate (SGR), and feed conversion ratio (FCR) determined according to the temperature change. Food intake has positive correlation to specific growth rate (Qiang at al. 2012).

Cowey ve Luquet (1983) described that temperature changes also lead to changes in the rate of protein synthesis. There is currently insufficient information on whether this change in protein synthesis rates has a positive or negative effect overall. Increases in water temperature during the cultivation of cold water fish, in particular, can engender significant problems, and consequently significant losses.For instance, a recent study has shown that when the water temperature was 18 degrees $\mathrm{C}$, mortality due to $\mathrm{S}$. agalactiae was higher in rainbow trout than $12{ }^{\circ} \mathrm{C}$. Optimum temperature for growth provide the best performance of fish immune system. Non-specific and specific immune parameters in teleost decrease significantly when the water temperature is lower or higher than normal physiological range of the fish (Sepahi at al. 2013).

Changes in water conditions should normally take place slowly and gradually. In cases in which these changes take place more rapidly than normal and acceptable for the fish, their physiology will be adversely affected (Akı, 2000). For this reason, it is necessary to prevent the increase in water temperature and the decrease in the oxygen content of the water; in other words, the environmental requirements of the fish need to be fully satisfied(Akbulut, 2009; Dikel, 2009).

In certain circumstances, measurements are obtained by counting. A certain portion of data obtained through counting displays a Poisson distribution. Counting data are defined as the number of occurrences of a particular event during a predefined period. It is believed that variables composed of counting data can be analyzed using a linear regression model. However, the application of a linear regression model to counting data can lead to weak and inconsistent results (Ankaralı ve ark., 2005). The Poisson regression model is considered as the starting point for the analysis of counting data (Akın, 2002). As the Poisson regression model possesses the characteristics listed below, the least squares method is not employed for the estimation of model parameters; instead, the maximum likelihood estimation is used(Cameron and Triverdi, 1986; Hendrickx, 2002; Ankaralı ve ark., 2005; Deniz, 2005).

- For the dependent variable $Y$, the Poisson dispersion is necessary. In addition, the dependency condition must be satisfied for the proper and correct identification of the conditional mean.

- Statistical results calculated by using the maximum likelihood standard errors and the t-statistics necessitate the correct identification of both the conditional mean and variance. The condition that is sought in these circumstances is for the conditional variance and conditional mean to be equal to one another.

- If the conditional variance and conditional mean for the relevant data are not equal, the statistical results obtained through the use of the maximum likelihood method will be valid and correct in the case it is demonstrated that the conditional mean is accurately defined.

- If the conditional variance and conditional mean for the data are not equal, estimators that are more effective and accurate than the Poisson maximum likelihood estimator can be used.

If the calculated coefficients are not correctly interpreted, they will have limited significance for the model. For this reason, attention should be paid to the proper and correct interpretation of the coefficients.

Increases in temperature can lead to significant physiological changes in fish. These detrimental changes can further increase or decrease depending on the growth periods and the effect of environmental factors. As these changes were obtained by counting and were also observed in different timeframes, the obtained data demonstrated Poisson distribution (Mc Conell et al., 1995). As such, the application of a linear regression model can potentially provide weak data that are inconsistent with one another. In this study, we aimed to estimate the effect of temperature increases on trout by using a Poisson regression model instead of a linear regression model.

\section{MATERIALS AND METHODS}

The study was conducted at the Karaova Dam Lake within the Kırşehir Province. Rainbow trout(Oncorhynchus mykiss) was used as the study material. The fishes were regularly observed starting from the month of September, and efforts were made to identify fishes that were affected by temperature changes. Measurements were evaluated separately according to male and female fish specimens.

A total of 2000 fishes were placed inside special cages; while measurements were performed on these fishes, concurrent water temperature measurements were also obtained from the Karaova Dam Lake. The 
fishes were also weighed regularly. Water temperature and dissolved oxygen measurements were performed with a field oxygen meter measuring temperatures between $5^{\circ} \mathrm{C}$ and $45^{\circ} \mathrm{C}$ (with a sensitivity of $\pm 1^{\circ} \mathrm{C}$ ), and dissolved oxygen between 0-15 ppm (with a sensitivity of $\pm 0.2 \mathrm{ppm}$ ).

Standard feed was provided. Commercial extruded trout feed was used as feed material, which was given to the fish according to their size. Fish that showed no increases in weight or displayed slower development in comparison to the others were considered to have been adversely affected by

$$
\frac{c}{N}=e^{\alpha+\beta_{i} x_{i}+\varepsilon_{i}}
$$

In this equation:

c: Number of fish affected by temperatures

$\mathrm{N}$ : Total number of fish collected

$\alpha$ : Constant term

$\beta_{i}$ : Regression coefficient of the explanatory variable

$x_{i}$ : Explanatory variable

$\mathcal{E}$ : Error term

$e: 2.1718$ (Base of the natural logarithm)

Various goodness of fit tests were performed on the results of the analyses that were carried out. These tests are described below (Dobson, 2002; Özmen, 2003; Deniz, 2005).

$$
P=\sum_{i=1}^{n} \frac{\left(y_{i}-\hat{\mu}_{i}\right)}{\hat{w}_{i}}
$$

This value is used for determining whether the series displays overdispersion. In this formula, the $\hat{\mu}_{i}$ and $\hat{w}_{i}$ values represent the predicted values for $\mu_{i}$ and $w_{i}$. The calculated value for $P$ was compared with $(n-k)$

$$
P_{p}=\sum_{i=1}^{n} \frac{\left(y_{i}-\hat{\mu}_{i}\right)^{2}}{\hat{\mu}_{i}}
$$

The calculated $P_{p}$ value was similarly compared with the (n-k) value. As such;

$$
\begin{aligned}
& \text { If } P_{p}>\mathrm{n}-\mathrm{k} \text {, the series is said to have overdispersion } \\
& \text { If } P_{p}<\mathrm{n}-\mathrm{k} \text { the series is said to have underdispersion }
\end{aligned}
$$

2. Deviation Statistic: Another technique used for measuring the goodness of fit is the deviation statistic. This statistical value is also called the "Gsquared statistic." The G squared statistic is expressed as follows:

$$
G^{2}=2 \sum_{i=1}^{n} y_{i} \ln \left(\frac{y_{i}}{\mu_{i}}\right)
$$

temperature. The energy density changes depending on the temperature from 1 to $5 \mathrm{~g}$ per individual is less than the range of fish (Canale and Breck, 2013). Hence, it possible to determine the extent to which temperature affected fish growth. Measurements were performed at one week intervals for a total period of nine months. Weight measurements of fish were humanely.We thus attempted to identify the effect of increases and decreases in water temperature on the fish. The obtained results were evaluated using the Poisson regression analysis. In this context, the following Poisson regression model was used:

1) Pearson Statistics: For any model of the dependent variable $y_{i}$, with a mean of $\mu_{i}$ and a variance of $w_{i}$, the standard method for measuring goodness of fit is the Pearson statistic, which is expressed as follows:

value, which is the determined degree of freedom for $\hat{\mu}$ . When this formula was applied to the Poisson distribution, it was determined that $w_{i}=\mu_{i}$, and the formula was rewritten as follows: 
If the value for this statistic converges to zero, it is possible to say that the model fit is increasing. If the value for this statistic is exactly equal to zero, it is then possible to say that the model has excellent fit.

$$
R_{p}^{2}=1-\frac{\log L(y)-\log L(\hat{\mu})}{\log L(y)-\log L(\bar{\mu})}
$$

Here, the log-likelihood functions are obtained as follows:

$$
\begin{aligned}
& \log L(y)=\sum_{i=1}^{n}\left(y_{i} \log \left(y_{i}\right)-y_{i}-\log \left(y_{i} !\right)\right) \\
& \log L(\hat{\mu})=\sum_{i=1}^{n}\left(y_{i} \log \left(\hat{\mu}_{i}\right)-\hat{\mu}_{i}-\log \left(y_{i} !\right)\right) \\
& \log L(\bar{y})=\sum_{i=1}^{n}\left(y_{i} \log \left(\bar{y}_{i}\right)-\bar{y}_{i}-\log \left(y_{i} !\right)\right)
\end{aligned}
$$

3. Artificial $\mathbf{R}^{2}$ Measurement: There is no common definition for $R^{2}$ employed for non-linear models. Due to this uncertainty, the term "Artificial" is used when expressing the calculated value. For the Poisson regression model, the $R_{p}^{2}$ value is defined as follows:

Organizing these log-likelihood functions provides the Artificial $R^{2}$ value.

4. Chi-Square goodness of fit test: The possible hypotheses used for evaluating the goodness of fit are as follows:

$\mathrm{H}_{0}$ : The data conform to the Poisson model. or,

$\mathrm{H}_{1}$ : The data do not conform to the Poisson model.

Pearson $\chi^{2}$ The Pearson $\chi^{2}$ statistic is calculated with the equation below:

$$
\chi^{2}=\sum_{i=1}^{j} \frac{\left(n \bar{p}_{j}-n \hat{p}_{j}\right)^{2}}{n \hat{p}_{j}}
$$

In this equation, $n \bar{p}_{j}$ represents the observed frequencies, while $n \hat{p}_{j}$ represents the theoretical frequencies. The result obtained with the aid of this equation $(\mathrm{N}-\mathrm{p})$ is compared with the degree of freedom value $\chi^{2} . N$ is the number of units, while $P$ is the number of parameters being estimated. If the calculated value exceeds the value $\chi_{N-p}^{2}$, the hypothesis is rejected, and the data are considered to conform to the Poisson model.

\section{RESULTS AND DISCUSSIONS}

The number of fish evaluated in this study, the number of fish demonstrating growth retardation, and the water temperatures are all shown in table 1 below.As shown in table 1, depending on the geographical location of the region of study conduct water temperatures differed. 
Table1: The number of fish among the studied rainbow trout demonstrating growth retardation with respect to gender, and the measured water temperatures

\begin{tabular}{|c|c|c|c|}
\hline \multirow{2}{*}{ Time } & \multicolumn{2}{|c|}{$\begin{array}{l}\text { Among the rainbow trout(Oncorhynchus mykiss), the number of fish } \\
\text { with very little or no increase in weight }\end{array}$} & \multirow{2}{*}{$\begin{array}{l}\text { Mean Water } \\
\text { Temperature }\end{array}$} \\
\hline & Female + & Male $\delta^{\lambda}$ & \\
\hline September & 34 & 31 & 21.4 \\
\hline October & 22 & 17 & 17.2 \\
\hline November & - & - & 12.1 \\
\hline December & 2 & 4 & 9.2 \\
\hline January & 1 & 4 & 10.5 \\
\hline February & - & 1 & 12.7 \\
\hline March & 5 & 7 & 15.2 \\
\hline April & 16 & 15 & 17.0 \\
\hline May & 12 & 19 & 18.3 \\
\hline Total & 102 & 98 & 133,6 \\
\hline Average & 11.3 & 10.9 & 14.84 \\
\hline
\end{tabular}

An evaluation of the number of fish demonstrating growth retardation revealed that temperature changes had a very significant effect on the Oncorhynchus mykiss. It was also observed that both the decrease in weight gain and the loss of weight among the fish varied significantly with respect to gender.
The regression equations obtained as a result of the Poisson regression analysis are shown in Table 2. An evaluation of Table 2 shows that the effects of temperature were reflected onto the equation at different rates.

Table 2: The regression equations obtained as a result of the Poisson regression analysis.

\begin{tabular}{|l|l|l|}
\hline \multirow{2}{*}{ Oncorhynchus mykiss } & \multicolumn{1}{|c|}{ Gender } & \multicolumn{1}{c|}{ Parity } \\
\cline { 2 - 3 } & Memale $\uparrow$ & GRAF / TNF=Exp(57.26+1.4215 temperature $)$ \\
\hline GRAF: growth retardation among the fish & GRAF / TNF=Exp(62,4875+2.1009 temperature) \\
TNF : total number of fish \\
Exp: base of natural logarithms (2.71828)
\end{tabular}

The increase in temperature had a significantly detrimental effect on the rainbow trout. Increasing temperatures led to growth retardation among the fish. According to the estimations that were performed, a continuous increase in temperature resulted in a parallel increase in the number of trout demonstrating signs of growth retardation. The detrimental effects on the trout increased over time, leading to significant potential economic losses.
The evaluation results of the Poisson regression analysis for the goodness of fit are shown in Table 3. An evaluation of the table reveals that the Pearson statistic value for rainbow trout was determined as 9 , while the deviation statistic value was determined as 7 , the Artificial $R^{2}$ value was determined as 7 , and the chi-square goodness of fit value was determined as 2.

Table 3: Results of the Poisson regression analysis for the goodness of fit

\begin{tabular}{|l|c|c|}
\hline \multirow{2}{*}{ Goodness Fit of Tests } & \multicolumn{2}{|c|}{ Rainbow Trout } \\
\cline { 2 - 3 } & Female $q$ & Male $0^{+}$ \\
\hline Pearson Statistic & 8.24 & 9.01 \\
\hline Deviation Statistic & 8.45 & 8.63 \\
\hline Artificial R & 75.40 & 69.12 \\
\hline Chi-Square & 24.02 & 23.68 \\
\hline
\end{tabular}

Based on these results, it is possible to state that the data demonstrated overdispersion. With respect to the coefficient of determination, an explanation rate of $78.15 \%$ was identified, which represented a good value. However, the coefficient of determination was higher in comparison to the other values in the literature obtained through measurements. As our coefficient of determination was obtained from values determined through counting, this value might be considered as sufficient. In case the deviation statistic and Chi-Square statistical values $(n-p)$ (with $n$ : the number of observation, and p:the number of parameters in the model) are smaller than the value of the chi-square table with degrees of freedom, the model estimations are considered correct. As such, it was observed that the model, taking into account both the deviation statistic and the chi-square, had a good fit. Based on the Poisson regression analysis, it was observed that the temperature levels had an adverse effect on the growth of the rainbow trout, and that this effect was of considerable significance. There is a range of water temperature (about $7-18{ }^{\circ} \mathrm{C}$ ), where the appetite of rainbow trout is optimal. Outside of this range, at lower and higher water temperature, fish lose appetite. 
Finally, at too low or too high water temperature, fish stop feeding (Woynarovich at al. 2011). This is similar to our results. Linear regression model may be insufficient in the case of discrete variables (Seber and Wild, 1989). However, poisson regression model has many applications, not only to the analysis of counts of events, but also in the context of models for contingency tables and the analysis of survival data (Rodríguez, 2007).

In this study, the mean values of the Poisson regression model for the number of fish displaying growth retardation also provided the variance value. In addition to this, it was determined that the variance in real data was larger than the mean value. Such results are observed when there are a large number of zeros within the data. According to the results obtained during the study, it was determined that the study data displayed overdispersion. While certain researchers have described that a dispersion value of this level can be ignored, other researchers have emphasized that dispersion values should be evaluated even if they are close to 1 (Wang ve ark., 1996; Wang ve Putterman, 1998; Özmen, 1998; Dalrymple ve ark., 2002).In Yeşilova (2003)'s study investigating the overdispersion observed in certain data with the Poisson regression, a mixed Poisson model was applied to data demonstrating overdispersion. The mixed Poisson regression analysis was performed in different subpopulations. However, as the size of the subpopulation increased, it was observed that the goodness of fit values increased as well. Based on this observation, the studied trout were not divided into subgroups based on the assumption that this would increase the goodness of fit values. Based on our study results, we concluded that increasing temperatures had a negative effect on the growth of the rainbow trout.

\section{REFERENCES}

Akbulut B., (2009). Çoruh Nehri'nde Bulunan Balık Türlerinin Sıcaklık, Oksijen, Besin ve Habitat İstekleri Üzerine Incelemeler. Artvin Çoruh Üniversitesi Orman Fakültesi Dergisi, 10 (1):29-36

Akı K., (2000). Balık Sağlığında Profilaktik Önlemler ve Su Kalitesinin Önemi. Doğu Anadolu Bölgesi IV. Su Ürünleri Sempozyumu. 28-30 Haziran. Erzurum. 755-767.

Akın F. (2000). Kantitatif Tercih Modelleri Analizi. Ekim Kitapevi. Bursa

Ankaralı H., Mendeş M., Akkuş Z., Erden S., Erdoğan S., Keskin S., Toros F., (2004). Mersin'de Yaşayan Çocuklarda İntihar Girişim Sıklığı İçin Poisson Regresyon Modelinin Kullanımı. VIII. Ulusal Biyoistatistik Kongresi 20-22 Eylül Bursa, 138.

Brett J.R., Groves T.D.D., (1979). Physiological energetics. In: Hoar, W.S., Randall, D.J.,Brett, J.R. (Eds.), Fish Physiology. Bioenergetics and Growth, vol. 8. Academic Press, New York, 279- 352.

Cameron C., Trivedi P., (1998). Regression Analysis of Count Data, Cambridge, Cambridge University Pres.
Canale, R.P., Breck, J.E., (2013). Comments on proper (and improper) solutions of bioenergetic equations for modeling fish growth. Aquaculture. 404:41-46

Cowey C.B., Luquet P. (1983). Physiological basis of protein requirements of fishes. Critical analysis of allowances. In: Protein Metabolism and Nutrition. Symp. Int. Me'tabolisme et Nutrition Azote's, Clermont - Ferrand France., INRA publ., Vol. 1, 365-384.

Dalrymple M.L., Hudson, I., L., Ford, R. P. K., (2002). Finite Miture Zero-Inflated Poisson and Hurdle Models with Application to SIDV. University of Cantenbury, Christchurch, New Zeland, 19.

Deniz Ö., (2005). Poisson Regresyon Analizi. İstanbul Ticaret Üniversitesi Fen Bilimleri Dergisi. Yıl: 4, Sayı: 7. Bahar 2005/2. 59-72.

Dikel S., (2009). Su Sıcaklığının Balık Yetiştiriciliğine Etkisi. Alınteri (B):42-49.

Dobson A., (2002). An Introduction to Generalized Linear Models, Boca Raton, Chapman and Hall.

Grans, A., Seth, H., Axelsson, M., Sandblom, E., Albertsson, F., Wiklander, K., Olsson, C., (2013).Effects of acute temperature changes on gut physiology in two species of sculpin from the west coast of Greenland. Polar Biology. 36(6):775-785

Hendrickx J., (2002). Review of Regression Models for Categorical Dependent Variables Using Stata by Long and Freese

Larsen, B.K., Skov, P.V., McKenzie, D.J., Jokumsen, A., (2012). The effects of stocking density and low level sustained exercise on the energetic efficiency of rainbow trout (Oncorhynchus mykiss) reared at 19 degrees C. Aquaculture. 324:226-233

Mc Conell K.E., Strand I.E. and Blake-Hedegs L., (1995). Random utility models of recreational fishing: Cathing Fish Using a Poisson Process. Arine Resourches Economics. 10:247-261.

Nault L.R., (1998). Dalbulus maidis identification, biology, ecology and pest status. In: Diagnosing Maize Diseases in Latin America (Eds. C. Casela, R. Rentro and A.F. Krattiger). ISAAA Briefs No. 9. ISAAA: NY. 18-21.

Özmen İ., (2000). Quasi Likelihood/Moment Method for Generalized and Restricted Poisson Regressiopn Modelss and Its Application. Biometrical Journal 42(3):300-314.

Özmen İ., (2003). Poisson Regresyon Modeli İçin Düzeltilmiş Belirtme Katsayıları. Antalya 3. İstatistik Kongresi, 75-79, 16-20 Nisan 2003, Antalya.

Rodríguez, G., (2007). Lecture Notes on Generalized Linear Models. http://data.princeton.edu/wws509/notes/

Seber, G.A.F., Wild, C.J., (1989). Nonlinear Regression, Wiley, New York

Wang, P., Cockburn, I.M., Puterman, M.L. (1998). Analysis of Patent Data-Mixed Poisson Regression Model Approach. Journal of Business and Economic Statistics. 16(1):2741.

Wang, P., Puterman, M.L., Cockburn, I.M.; Le, N. (1996). Mixed Poisson Regression Models with Covariste Dependent Rates, Biometrics. 52:381-400.

Yeşilova, A. (2003). Biyolojik Çalışmalardan Elde Edilen Kategorik Verilere Karışık Poisson Regresyon Analizinin Uygulanması. Doktora Tezi. Y.Y.Ü. Fen Bilimleri Enstitüsü. Van. 